\title{
The concept of vulnerability applied to Healthcare-associated Infections
}

\author{
O conceito de vulnerabilidade aplicado às Infecções Relacionadas à Assistência à Saúde \\ El concepto de la vulnerabilidad aplicado a las Infecciones Relacionadas con la Atención de la Salud
}

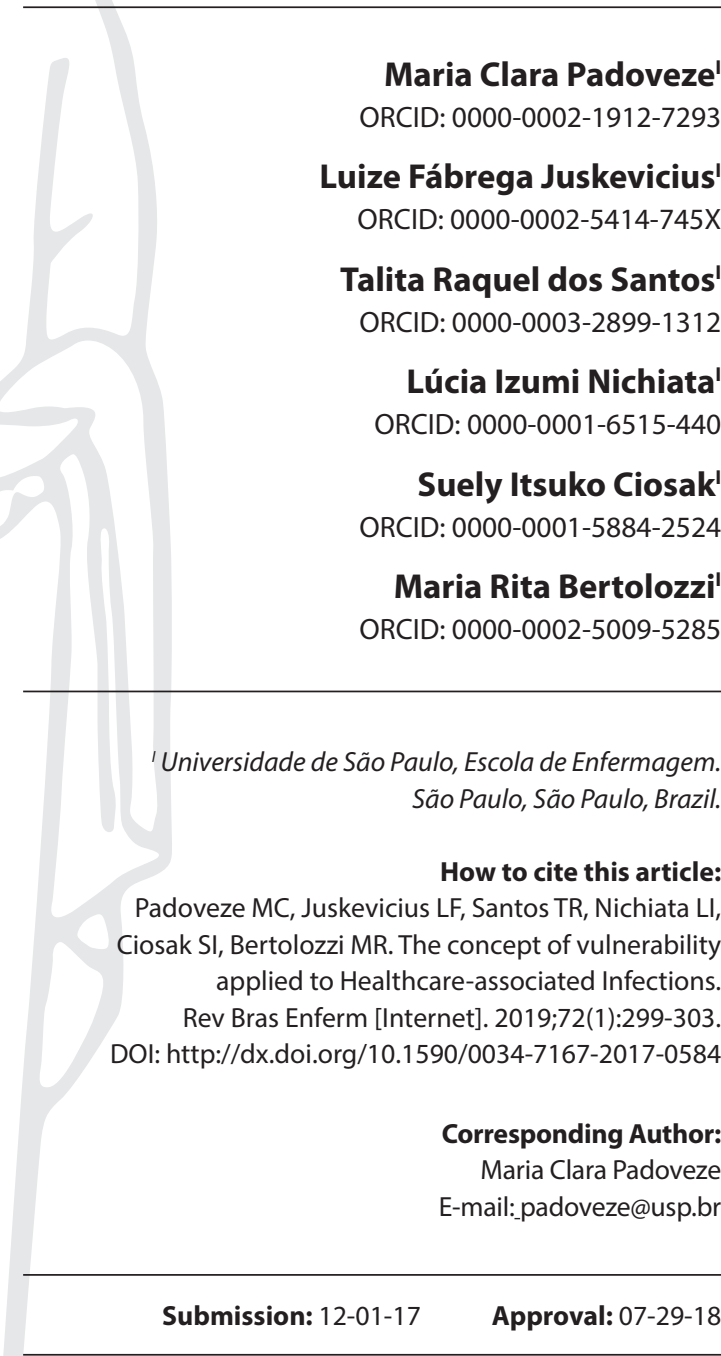

\begin{abstract}
Objective: To discuss the potentialities of using the concept of vulnerability to support measures for preventing and controlling healthcare-associated infections (HAls). Methods: This theoretical study was conducted in steps: 1) presentation of markers that frame the concept of vulnerability; 2) presentation of the characteristics of the health events to which the concept of vulnerability is intended to be applied; 3 ) identification of research gaps that could be potentially filled by using the concept of vulnerability; 4) identification of the potentialities of using the concept of vulnerability to deal with HAls. Results: Proposal of a framework for analyzing HAls from a vulnerability perspective, including the individual and collective dimensions. Conclusion: Using the concept of vulnerability to study and deal with HAls favors a new approach to an old problem, unlike the dominant studies that highlight the individual aspects of the practices in healthcare services.
\end{abstract}

Descriptors: Hospital-Acquired Infection; Vulnerability; Nursing; Infectious Disease; Contagious Disease.

\section{RESUMO}

Objetivo: discutir as potencialidades do uso do conceito de vulnerabilidade para embasar as ações de prevenção e controle das Infecções Relacionadas à Assistência à Saúde (IRAS). Método: estudo de base teórica, realizado em etapas: 1) apresentação dos marcadores que compõem o conceito de vulnerabilidade; 2) apresentação das características do agravo ao qual se pretende aplicar o conceito de vulnerabilidade; 3) identificação de lacunas de pesquisa que podem ser potencialmente preenchidas por meio do uso do conceito; 4) identificação das potencialidades do uso do conceito para o manejo de IRAS. Resultados: proposta de um quadro de análise das IRAS na perspectiva da vulnerabilidade, compondo dimensões individual e coletiva. Conclusão: o uso do conceito de vulnerabilidade no estudo e manejo de IRAS favorece um novo olhar sobre um antigo problema, diferente dos estudos hegemônicos que tratam de destacar os aspectos individuais relativos às práticas de atenção nos serviços de saúde. Descritores: Infecção Hospitalar; Vulnerabilidade; Enfermagem; Doença Infecciosa; Doença Transmissível.

\section{RESUMEN}

Objetivo: Discutir las potencialidades del uso del concepto de la vulnerabilidad para basar las acciones de prevención y control de las Infecciones Relacionadas con la Asistencia Sanitaria (IRAS). Método: Estudio de base teórica, realizado en etapas: 1) presentación de los marcadores que componen el concepto de la vulnerabilidad, 2) presentación de las características del agravio al que se pretende aplicar el concepto de la vulnerabilidad; 3) identificación de las lagunas de investigación que pueden ser potencialmente cumplimentadas por medio del uso del concepto; 4) identificación de las potencialidades del uso del concepto para el manejo de las IRAS. Resultados: Propuesta de un marco de análisis de las IRAS bajo la perspectiva de la vulnerabilidad, componiendo dimensiones individuales y colectivas. Conclusión: El uso del concepto de la vulnerabilidad en el estudio y manejo de las IRAS favorece una nueva mirada sobre un antiguo problema, diferente de los estudios hegemónicos que tratan de destacar los aspectos individuales relativos a las prácticas de atención en los servicios de salud. Descriptores: Infección Hospitalaria; Vulnerabilidad; Enfermería; Enfermedad Infecciosa; Enfermedad Transmisible. 


\section{INTRODUCTION}

Using the concept of vulnerability in healthcare is a recent event. It is necessary to go beyond the term's ordinary meaning and grasp its ontological concept, assigning new deeper meanings to it based on wider theoretical frameworks ${ }^{(1)}$. According to the meaning used in this study, the term vulnerability seeks to understand and change a given health process or phenomenon from a sociopolitical perspective.

Vulnerability emerges as a theoretical framework to meet the social needs that require knowledge and change of reality. A good example of vulnerability in healthcare is the HIV/AIDS pandemic. HIV/AIDS has shown that an adequate response challenges the very social system and demands the contribution from other areas of knowledge, that is, not only the traditional healthcare areas, but also the Humanities ${ }^{(1)}$. The pandemic showed that the concept of risk, which is key to Epidemiology and Public Health, was not enough to control it successfully and even worsened the attitudes and feelings of stigma and the discrimination against and "scapegoating" of individuals affected by the disease ${ }^{(2)}$.

The concept of vulnerability contributed to the change in the meaning assigned to HIV/AIDS as an effort to surpass the notion of risk, both individual and collective, and further understanding the social vulnerability to the infection and the epidemic. This understanding was needed to produce a global response to the infection spreading ${ }^{(2)}$. The development of this concept has enabled an increase in knowledge and the introduction of effective interdisciplinary practices ${ }^{(1)}$. It is a concept that has been widely adopted in Nursing ${ }^{(3)}$ and has allowed practical nurses and researchers in different locations to share their knowledge, thus improving nursing skills and practices.

As a tool for prevention strategies, vulnerability considers the target problem from a population susceptibility perspective. As a result, a social response with greater potential for minimizing or solving the target problem is expected. In this context, the herein research question emerges: "Is it possible to apply the concept of vulnerability to healthcare-associated infections (HAls)?"

\section{OBJECTIVE}

To present and discuss the potentialities of using the concept of vulnerability to support measures for preventing and controlling healthcare-associated infections (HAls).

\section{METHODOLOGICAL PATH}

This theoretical study was conducted in four steps: 1) presentation of markers that frame the concept of vulnerability; 2) presentation of the characteristics of the health events (HAls) to which the concept of vulnerability is intended to be applied; 3 ) identification of research gaps that could be potentially filled by using the concept of vulnerability; 4) identification of the potentialities and fragilities of using the concept of vulnerability.

Elementary and applied bibliographies of the concept of vulnerability and of the knowledge of critical epidemiology were considered to develop this methodological path. Theoretical studies were presented and debated with experts at the meetings of the research group registered at the National Council for Scientific and Technological Development (CNPQ) as "Vulnerability, Adherence and Needs in Collective Health", at the School of Nursing of the Universidade de São Paulo, from February to December, 2016

\section{Markers that frame the concept of vulnerability}

In healthcare, when initially analyzing the HIV/AIDS pandemic, the concept was defined as "the likelihood of individuals to acquire the infection due to several aspects that, even when directly related to the individual, are also related to the collective in which this individual is included. It is proposed an analysis of distinct degrees of vulnerability to the epidemics according to markers that frame the interdependent individual and collective (social and programmatic) dimensions ${ }^{(2)}$. Objectively, a marker serves as a warning signal, dealing with that or whom it marks or is used to mark, according to Health Sciences Descriptors (Bireme - Latin American and Caribbean Center on Health Sciences). As same as the yellow traffic light for cars, it warns of a risky situation and, therefore, it signals the appropriate safety measures. A marker is understood as a qualifying element that materializes what is contained in the dimensions of vulnerability. It is different from a health indicator, which is characterized as a risky measure and is mathematically calculated and represented ${ }^{(3)}$.

The individual dimension is based on the individual's life aspects that can potentially cause sickness. The social dimension considers the health/illness process as a social process and seeks to focus directly on the contextual factors that determine the vulnerability to health events. The programmatic dimension includes how institutions express health policies, either to reproduce or to minimize vulnerability to a given health event. Although organized into different categories, these dimensions are indivisibly related to each another. They were categorized for didactic purposes to favor a better capture of the phenomenon under this study. Yet, in real life the individual dimension aspects and the social and programmatic dimensions aspects are interrelated, given that the individual influences and is influenced by the collective. The imagery of the Rubik's Cube puzzle has been used to represent the concept of vulnerability by showing the interrelation between the sides (dimensions) that form a single entity.

In Brazil, the concept of vulnerability has been debated and set apart from the concept of risk, even though they are interrelated. In classic epidemiology, the concept of risk plays a central role and have an analytical character based on probabilistic associations. The concept of vulnerability, in its turn, has a synthetic nature based on the likelihood of individuals to be exposed to the infection according to the relation between several individual and collective aspects and the resources available for protection, allowing markers of social inequality to be captured. Vulnerability expands the idea behind the concept of risk, since it is not restricted to identifying the profile of the individuals affected by a disease but deepens the understanding of what causes it and adds a prospective vision of what resources could be used to combat it collectively ${ }^{(1)}$. By adopting vulnerability as a conceptual keystone attempting to its dialectical nature, it means that the proposed reference framework favors the ability to create, both 
individually and collectively, to overcome vulnerability conditions through participative and liberating processes.

\section{Characteristics of healthcare-associated infections}

The designation "healthcare-associated infections" (HAls) is a progression from and an amplification of the conventional "hospital-acquired infection" concept. Traditionally, a hospitalacquired infection is any infection acquired during hospital stay and that had not yet appeared or was in incubation period when the patient was admitted to the hospital. Yet, in its new meaning, the concept of HAls also includes infections acquired in non-hospital facilities.

The acquisition of HAls in hospitals has been studied in more detail due to their frequency, severity and costs. There is abundant national and international bibliography with recommendations and guidelines on the topic. However, with the diversification of settings where health care is provided, hospitals are no longer the only place where adverse events can occur due to the care received ${ }^{(4)}$. Among these adverse events, the acquisition of infections is a real possibility. The likelihood of acquiring infections increases with the growing number of invasive procedures and the high susceptibility of populations due to specific conditions of individuals (such as base extremes, immune-suppressing diseases or medication, obesity and malnutrition). Therefore, changes in the characteristics of the population served by non-hospital facilities will potentially cause changes in the magnitude of HAls incidence in these facilities. Hence, the use of the term HAI not only changes a traditional term but also implies a trend towards a more comprehensive perspective on the phenomenon.

HAls can have many causes and be produced by any microorganism, which can cause mild, moderate and severe infections that can be manifest in any region of the body. They can be associated with any kind of procedure performed at any kind of healthcare facility. Peculiarly, it is a two-way phenomenon, affecting both healthcare facilities users and health workers. Remarkably, there is a double face in it: the intervention is at the same time the solution and the problem itself, since the assistance, although aimed at restoring health, is also the potential producer of adverse events such as HAls. Additionally, there are situations in healthcare facilities that favor the selection and spreading of antimicrobial and germicidal-resistant agents.

The knowledge of HAls has passed through different evolutionary conceptual stages. Initially, they were considered merely as events linked to hygiene, and intervention consisted of monitoring sanitary conditions. Afterwards, they started to be considered from the classic epidemiological perspective, and studies associated risk factors with the hospital environment. Recently, they have been recognized as a public health issue to whose prevention recommendations have been made. It is important to highlight that the number of HAl cases is up to 20 times higher in developing countries than in developed countries. In fact, developed countries have created more developed government programs for combating $\mathrm{HAls}^{(5)}$. The use of $\mathrm{HAI}$ prevention programs became globally recognized as a priority in developed countries, especially after the tragic experience with the Ebola virus in Africa, the recent epidemics of Middle East
Respiratory Syndrome Coronavirus (MERS-CoV), and the latest influenza virus pandemic ${ }^{(6)}$.

Although Brazil has made considerable progress regarding healthcare prevention programs in the last two decades, structure fragilities remain ${ }^{(7)}$. Government systems of epidemiological surveillance have been introduced, but they still need to be improved $^{(8)}$. According to data from the latest prevalence study conducted in Brazil, roughly 1 out of every 10 patients admitted to hospital will be affected by HAls ${ }^{(9)}$.

$\mathrm{HAls}$ are related to the emergence of resistance to antimicrobial agents. Not all HAls are caused by resistant strains and not every case of resistance is associated with HAls, since resistance can also emerge from infections acquired in the community. However, the frequent use of antibiotics in healthcare services increases the ecological pressure that favors the selection of resistant strains. Additionally, these strains are easily spread in the hospital environment. This caused an increase in the global concern about HAls in the last years.

Another aspect of HAls is that these are diseases where"scapegoating" and stigmatization do not fall on users, but on health workers and facilities, which are perceived as "guilty" by the society and even in scientific literature. Yet, there is little debate on the context where these professionals work and on their work conditions and workload, which can increase the likelihood of emergence of certain infectious adverse events. Therefore, such complex health events can only be fully understood by using tools that enable a broader view of the phenomenon.

\section{Research gaps: the concept of vulnerability applied to healthcare-associated infections}

Traditional epidemiology has been driving national and global studies of the HAls. With recent progress on genetic studies of microorganisms, molecular epidemiology became an important and useful tool to increase the ability to understand this phenomenon. More recently, process indicators have been used together with conventional structure and result indicators. Hence, the potential for identifying the elements associated with adverse results has been increased, raising the efficacy of the proposed interventions. Despite the great importance of all these tools, it is still necessary to develop other tools that could, on its own, potentially broaden perspective and capture quantitative and qualitative markers of the phenomenon in its individual, social and programmatic dimensions. Therefore, it is believed that adding new tools could favor a more comprehensive analysis.

To deepen this HAls analysis, this study sought to identify which markers could reveal the vulnerability of individuals and populations to these health events. Vulnerability analyses do not exclude the need for classic epidemiological risk assessment to enable the recognition of a disease's magnitude and the establishment of probabilistic associations of the objective and measurable conditions that can cause the disease. However, to better identify and analyze these variables, and to propose efficient intervention methods, it is necessary to recognize the collective context where these diseases occur.

Commitment to Care presupposes beneficence and no maleficence at all. Thus, HAls are adverse results of Care, and their 
prevention and control are concerns also related to it. When related to the Care, the individual and collective aspects of $\mathrm{HAI}$ prevention are inseparable.

The assessment of vulnerability from the individual dimension perspective starts with the conception from each person in relation to the syndrome. In this case, the individual, conceived as a right-holder, is both the healthcare user and the health worker.

One of the research gaps to be filled is far beyond identifying sole biological markers associated to HAls but goes to questioning to what extent the individual that seeks health care knows the risks involved. In addition, it raises the question of how much knowledge of these risks health workers have. Do healthcare users know what is the role of the health professionals, government, and their own role in the prevention process? Are the prevention methods well-known as well the right to them and the right of users to question health workers' practices? For instance, can the vulnerability of each individual hospitalized under transmission based precautions be influenced by the patient's knowledge, perception and engagement in therapy? Do professionals recognize that healthcare users have the right to question the practices of health workers? Can the bond developed between professionals and users influence the rates of adherence to HAI prevention measures?

From the social dimension perspective, a matter of investigation is whether racial, cultural, economic e geographic factors interfere in how HAls are perceived and in how prevention measures are accepted. Certain practices and social concepts might favor blaming institutions and health workers for HAls. On the other hand, it is important to analyze how much the lack of social interest in the phenomenon drives healthcare policy makers to carelessness.

Many other markers such as accessibility to healthcare settings are also potential research question. For instance, can the lack of adequate health care, the over-crowded health facilities (such as nurseries, ICUs and hemodialysis centers) and the staff workload or downsizing cause complications that favor HAl acquisition? It is highly possible that delayed healthcare interventions are associated with likelihood of HAI. In many cases patients should be handled in primary care instead of being hospitalized and unnecessary admissions could be avoided ${ }^{(4)}$. When needed, hospital admissions should occur at opportune time to avoid performing procedures under conditions where complications already exist.

Another question that can be raised is how poor access to good-quality material impacts HAI rates. Can the lack of adequate material impact not only the service provided to healthcare users but also the safety of health workers? There are many other gaps regarding to strategies to allow health workers to participate in decisions on the establishment of standard operating procedures (SOPs) and continuing education programs.

Finally, from the programmatic dimension perspective, it is necessary to identify how services are committed to prevention programs, to the organization of teams, allocation of resources and improvements. In this dimension, intersectoral management is essential and must include training for the professionals. Additionally, it is paramount to recognize that microbial resistance is not restricted to healthcare services and, therefore, it must be addressed in cooperation with other fields, such as farming and veterinary medicine. Comprehensiveness of care must also be considered when dealing with HAls prevention programs. The links between reference and counter-reference among primary, secondary and tertiary levels are fundamental. The concept of comprehensiveness must be considered at every health care step, from the orientation to healthcare users up to the surveillance of HAls detected after discharge.

Considering all these questions, it is clear that there are many gaps to be filled regarding the knowledge of the HAI phenomenon. On this matter, the concept of vulnerability can contribute to establish a new reference framework to enable a broader assessment of HAls and potential prevention strategies. This framework is expected to serve not as a mere scoring system, but as a kind of qualitative, critical-reflexive assessment.

\section{Potentialities of adopting the concept of vulnerability to deal with healthcare-associated infections}

The different ways of world vision determine how societies manage their potentialities and fragilities. Until now, conventional epidemiological concepts have not helped to fully solve health problems.

The concept of vulnerability favors a broader viewing of the phenomenon and enables a look at the individual within his sociopolitical context. Vulnerability enables the identification of weaknesses and strengths which increases the likelihood of defeating diseases, since the individual is not passive in the process. Accordingly, from the vulnerability perspective, interventions to prevent HAls can differ from conventional strategies, since they will not be rigid recommendations as packages of measures in the "top-down" model.

The introduction of the concept of vulnerability to research and practices of $\mathrm{HAI}$ prevention can potentially lead to addressed social actions that favor and promote equal access to healthcare, reduce the stigmatization of health workers and services and ensure interdisciplinarity. It is essential to unveil the premise that $\mathrm{HAl}$ prevention is a citizen right, and therefore the society must be allowed to participate in detecting and fighting HAls, thus acknowledging the co-responsibility of the different elements involved in the process. Chart 1 shows a summary of potential markers of vulnerability of individuals to HAls. This summary is a proposal for future studies.

Hopefully, studies based on the concept of vulnerability will encourage the development of public policies regarding $\mathrm{HAI}$ prevention, mainly in Brazil. These policies shall include a clear definition of the role of healthcare settings, and local, state and federal government. These policies must prove sustainable, stand along to the principles of the Unified Health System (SUS) and be ensured by the State.

In conclusion, using the concept of vulnerability to study and manage HAls enables a new approach to an old problem. This promotes equity and comprehensiveness in the actions, encourages social participation, reestablishes a notion of risk that goes beyond the individual, and reduces the stigmatization of healthcare professionals and facilities. 
The concept of vulnerability applied to Healthcare-associated Infections Padoveze MC, Juskevicius LF, Santos TR, Nichiata LI, Ciosak SI, Bertolozzi MR.

Chart 1 - Summary of dimensions and markers of vulnerability of healthcare users and workers to healthcare-associated infections (HAls), São Paulo, Brazil, 2018

\begin{tabular}{|c|c|c|}
\hline \multirow{2}{*}{$\begin{array}{c}\text { INDIVIDUAL } \\
\text { (Healthcare user and worker) }\end{array}$} & \multicolumn{2}{|c|}{ COLLECTIVE } \\
\hline & SOCIAL & $\begin{array}{c}\text { PROGRAMMATIC } \\
\text { (Healthcare policy and service organization) }\end{array}$ \\
\hline $\begin{array}{l}\text { - Recognition of the person as a right-holder; } \\
\text { - Level and quality of information on HAls and } \\
\text { prevention methods that individuals, families } \\
\text { and groups have; } \\
\text { - Existence or absence of pre-conditions } \\
\text { that reduce vulnerability (such as beliefs and } \\
\text { perceptions of HAls); } \\
\text { - Political participation; } \\
\text { - Adherence to prevention measures; } \\
\text { - Overall immunity condition, including } \\
\text { immunization of healthcare workers and users; } \\
\text { - Comorbidity conditions and previous } \\
\text { infections, presence of colonization or infection } \\
\text { by antimicrobial-resistant strains; } \\
\text { - Susceptibility related to risk factors, such } \\
\text { as age, immune-suppressing diseases or } \\
\text { medication, obesity, malnutrition, and smoking. }\end{array}$ & $\begin{array}{l}\text { - The country's socioeconomic development; } \\
\text { - Democratic foundations that ensure the } \\
\text { right to political participation; } \\
\text { - Public social policies; } \\
\text { - Relationship between State and civil society; } \\
\text { - Enough and regular funding for healthcare; } \\
\text { - Level of commitment to HAl prevention of } \\
\text { the different bodies from society; } \\
\text { - Access to healthcare; } \\
\text { - Access to education; } \\
\text { - Access to good-quality information; } \\
\text { - Stigma attached to HAls; } \\
\text { - Religious beliefs; } \\
\text { - Democratic areas used to promote political } \\
\text { participation. }\end{array}$ & $\begin{array}{l}\text { - How governments respect, protect and promote } \\
\text { the right to good-quality health care; } \\
\text { - Healthcare facilities organization and structure } \\
\text { (planning, assessing and monitoring) for providing } \\
\text { good-quality service; } \\
\text { - Establishment of public policies towards HAls; } \\
\text { - Goals and measures proposed by programs; } \\
\text { - Organization and distribution of resources for } \\
\text { HAl prevention and control; } \\
\text { - Existence of sensible, democratic foundations for } \\
\text { defining the content of HAl prevention programs; } \\
\text { - National and international standards for HAI } \\
\text { prevention and control; } \\
\text { - Sensible guidelines for the use of antibiotics and } \\
\text { invasive procedures; } \\
\text { - Information concerning the right to safety in } \\
\text { health care. }\end{array}$ \\
\hline
\end{tabular}

Source: Modified from Ayres et al. ${ }^{(10)}$

\section{FUNDING}

This study is part of the project "Assessment of programmatic vulnerability for the prevention of infections related to health care

in Basic Health Units of the Butantã Region of São Paulo City". Funding: São Paulo Research Foundation (FAPESP) - Case 2010/16729-1.

\section{REFERENCES}

1. Oviedo RAM, Czeresnia D. O conceito de vulnerabilidade e seu caráter biossocial. Interface Comun Saúde Educ [Internet]. 2015 ; [cited 2018 Jul 18];19(53):237-50. Available from: http://dx.doi.org/10.1590/1807-57622014.0436

2. Mann J, Tarantola DJM, Netter TW (Orgs.). A aids no mundo. Rio de Janeiro: Relume Dumará: Abia: IMAS-UERJ; 1993. Chapter Programas nacionais de combate a aids.

3. Nichiata LY, Bertolozzi MR, Gryschek AL, Araújo NV, Padoveze MC, Ciosak SI, Takahashi RF. The potential of the concept of vulnerability in understanding transmissible diseases. Rev Esc Enferm USP [Internet]. 2011 [cited 2018 Jul 18];45 Spec No 2:1769-73. Available from: http:// dx.doi.org/10.1590/S0080-62342011000800023. English, Portuguese.

4. Padoveze MC, Figueiredo RM. [The role of primary care in the prevention and control of healthcare associated infections]. Rev Esc Enferm USP. 2014;48(6):1137-44. doi: 10.1590/S0080-623420140000700023. Portuguese.

5. Allegranzi B, Bagheri Nejad S, Combescure C, Graafmans W, Attar H, Donaldson L, Pittet D. Burden of endemic health-careassociated infection in developing countries: systematic review and meta-analysis. Lancet. 2011;377(9761):228-41. doi: 10.1016/ S0140-6736(10)61458-4.

6. Allegranzi B, Kilpatrick C, Storr J, Kelley E, Park BJ, Donaldson L; Global Infection Prevention and Control Network. Global infection prevention and control priorities 2018-22: a call for action. Lancet Glob Health. 2017;5(12):e1178-e1180. doi: 10.1016/ S2214-109X(17)30427-8.

7. Padoveze MC, Fortaleza CM, Kiffer C, Barth AL, Carneiro IC, Giamberardino HI, Rodrigues JL, Santos Filho L, de Mello MJ, Pereira MS, Gontijo Filho P, Rocha M, de Medeiros EA, Pignatari AC. Structure for prevention of health care-associated infections in Brazilian hospitals: A countrywide study. Am J Infect Control. 2016;44(1):74-9. doi: 10.1016/j.ajic.2015.08.004.

8. Padoveze MC, Melo S, Bishop S, Poveda VB, Fortaleza CMCB. Public policies on healthcare-associated infections: a Brazil and UK case study. Rev Saúde Publica. 2017;51:119. doi: 10.11606/S1518-8787.2017051000315.

9. Fortaleza CMCB, Padoveze MC, Kiffer CRV, Barth AL, Carneiro ICDRS, Giamberardino HIG, Rodrigues JLN, Santos Filho L, de Mello MJG, Pereira MS, Gontijo Filho PP, Rocha M, Servolo de Medeiros EA, Pignatari ACC. Multi-state survey of healthcare-associated infections in acute care hospitals in Brazil. J Hosp Infect. 2017;96(2):139-144. doi: 10.1016/j.jhin.2017.03.024.

10. Ayres JR, Calazans GJ, Saletti Filho HC, França Jr I. Risco, vulnerabilidade e práticas de prevenção e promoção da saúde. In: Campos GW, Minayo MC, Akerman M, Drumond Jr M, Carvalho YM. Tratado de saúde coletiva. São Paulo: Hucitec/FioCruz; 2009. p. 375-417. 